\title{
Chapter 17 \\ The Mottled Legacy of 9/11: A Few \\ Reflections on the Evolution \\ of the International Law of Armed \\ Conflict
}

Charles J. Dunlap Jr.

\section{Contents}

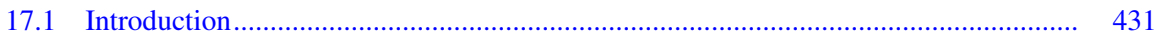

17.2 Law in Twenty-First Century Operations............................................................... 432

17.3 The Disappointing Performance of UN............................................................... 434

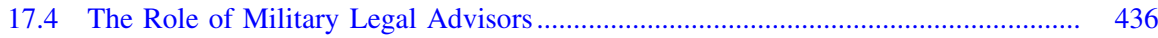

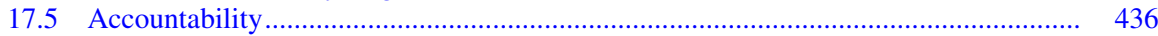

17.6 Terrorist Detention .............................................................................. 438

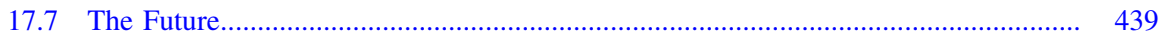

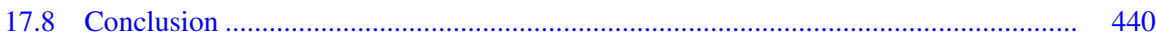

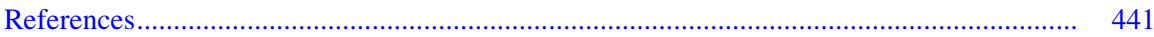

\subsection{Introduction}

Has the way the law evolved since $9 / 11$ been an unqualified good? Some might think so. Undoubtedly, there have been many positive developments in international law in general, and the international law of armed conflict (ILOAC) ${ }^{1}$ in

\footnotetext{
1 This essay will use the term "international law of armed conflict" (ILOAC) in lieu of the appellations "law of war" (LOAC) and "international humanitarian law" (IHL), both of which are, in this writer's view, too inexact and subject to misinterpretation. "Law of war" inevitably involves thorny questions of "what is "war'?" variety even in situations where discussants agree that there is an "armed conflict." Like many Americans, this writer views the term "international humanitarian law" as one that dangerously seems to suggest that conflicts can somehow be made more humane that reality would permit. What is more is that it can too easily be conflated with "international human rights law" which is, of course, a very distinct legal regime.
}

C. J. Dunlap Jr. ( $\square)$

USAF, Duke University Law School,

Durham, NC 27708-0358, USA

e-mail: dunlap@law.duke.edu 
specific. Certainly those disposed towards the peaceful resolution of disputes and the efficacy of international law are heartened by recent studies that show, rather counterintuitively, that violence, and especially interstate violence, is actually declining. ${ }^{2}$

Yet it is just as important to understand that not every ILOAC-related development has been positive, even if one believes that overall the constructive advances outweigh the unhelpful ones. Indeed, this brief essay contends that while the increasing influence of law on armed conflict since 9/11 generally operates to diminish the human suffering that warfare traditionally occasions, there are nevertheless some disturbing trends that deserve considered attention.

Among the concerns are misplaced actions that encourage behaviors that may, over time, prove profoundly inimical to the fundamental purposes of ILOAC. In particular, this article contends that ILOACs efforts to grapple with the challenge of non-state actors engaged in armed conflict and terroristic acts is too often having the perverse effect of seeming to reward noncompliance with ILOAC, and thus-paradoxically-incentivizing further violations of the law.

All the same, this article will also point out positive evolutions such as the increasing importance of military lawyers, and their growing ability to influence military operations. Finally, the essay will offer some predictions as to the direction of the law in the next decade and beyond.

\subsection{Law in Twenty-First Century Operations}

9/11 coincided with several ongoing phenomena that while fully separate from the law, qua law, nonetheless have deeply affected ILOAC. Chief among these is the impact of globalization. Globalized commerce has stimulated the need not just for international law and international forums in order to conduct trade rationally and profitably, it has also internationalized a legal mindset among nations that heretofore have not needed to consider the impact of law. Today, their engagement with law is essential to their ability to function in the larger world. In short, countries wishing to profit-literally-from globalized trade need legal architectures that ensure agreed upon rights and responsibilities, as well as some means of enforcement.

Predictably, this market-driven trend caused a renaissance of sorts for international law. As has always been the case, whatever develops in the commercial sphere inevitably impacts the conduct of war. The development of the internal combustion engine, for example, led to the emergence of armored warfare and air warfare. More recently, the invention of the microchip has completely revolutionized warfare by permitting the development of highly-precise munitions, as well as unprecedented reconnaissance and surveillance technologies. Perhaps of equal importance with

2 Goldstein 2011. 
respect to ILOAC, the microchip spawned an array of communications technologies that enable the live (or near-instantaneous) broadcast of battlefield events across the globe.

These two phenomena- the rise of international law generally, and the changes wrought by microchip-based technologies-are among the leading causes of the emergence of what this author termed in 2001 as "lawfare". 3 Although it has often been given a nefarious interpretation as being the transformation of law into a weapon for terrorists to wage war against the law-abiding, it actually is a neutral concept. It conceptualizes the law much as a weapon that can be used for good or malevolent purposes.

The key, however, is that legal warfare-however bitter-is presumptively preferable to kinetic conflict. In this respect, lawfare carries the potential to achieve the aim of ILOAC generally, which is to mitigate the physical horror of war, if not eliminating it altogether. In other publications the author discusses in some detail how law might be used in just such an affirmative way to advance that laudable goal. ${ }^{4}$ However, it is also true that adversaries-terrorists particularlyembrace a form of lawfare, one marked by the exploitation of actual violations of ILOAC by U.S. and other Western forces. Even more malevolently, they even try to orchestrate deadly incidents for the purpose of undermining the moral and political legitimacy of U.S. and other forces.

There is no question that events such as the detainee abuses at Abu Ghraib or, more recently, the videos of U.S. Marines urinating on the bodies of Taliban fighters, are the kind of illegalities that readily translate into battlefield advantages for adversaries. ${ }^{5}$ In the years since $9 / 11$ adversaries have internalized the concept that one of the best ways to unhinge U.S. and Western forces is via the civilian casualty issue. Professors Michael Riesman and Chris T. Antoniou presaged this in their 1994 book, The Laws of War:

In modern popular democracies, even a limited armed conflict requires a substantial base of public support. That support can erode or even reverse itself rapidly, no matter how worthy the political objective, if people believe that the war is being conducted in an unfair, inhumane, or iniquitous way. ${ }^{6}$

Unsurprisingly, former Secretary of Defense Robert Gates believed that a "principal strategic tactic of the Taliban...is either provoking or exploiting civilian casualties." 7 This has been exacerbated by the disconcerting trend, it seems, to "improve" upon ILOAC by announcing presumably well-intended policies that can, perversely, operate to frustrate ILOAC goals.

A classic example is how NATO forces handled allegations of excessive civilian casualties in Afghanistan. In an apparent effort to sooth local outrage,

\footnotetext{
3 Dunlap 2001.

4 Dunlap 2010.

5 Kudo 2012.

6 Reisman and Antoniou 1994, p. xxiv.

7 DoD 2009.
} 
NATO announced in 2007 that if it "knew there were civilians nearby," it would not conduct airstrikes ${ }^{8}$ A year later, NATO reiterated its stance-a stance demonstrably not dictated by legal imperatives-by asserting that no bombing would take place "[i]f there is the likelihood of even one civilian casualty... not even if we think Osama bin Laden is down there." 9

This is exactly the kind of ILOAC development that, wholly counterproductively, encourages belligerents to burrow into civilian communities with the understandable expectation that they will thereby be shielded from air attack if they can manage to keep "one civilian" in the area. While efforts to protect civilians are admirable, as is restraint in the use of force, if the unintended consequences are not carefully thought out, they can have the effect of granting sanctuary to the forces most deadly to civilians in twenty-first century conflicts.

\subsection{The Disappointing Performance of UN}

Since $9 / 11$, the UN has not been a particularly positive force in the evolution of ILOAC. Perhaps its most disastrous initiative was its now considered to be flawed investigation into Operation Cast Lead, Israel's 2009 military operation in Gaza against Hamas militants. In the aftermath of the bloody clash, both sides traded allegations of war crimes. The UN commissioned former South African jurist and legal scholar Richard Goldstone to lead the investigation. The final report was mainly critical of Israel, accusing it of intentionally targeting civilians.

In a rather astonishing 2011 op-ed in the Washington Post Goldstone, while complaining about the lack of Israeli cooperation for his report, nevertheless admitted that given what was discovered by Israel's independent investigations, if he "had known then what [he] know[s] now, [his] report have been a different document." 10 He expressed disappointment that Hamas did not conduct its own investigation as Israel had, but conceded that "asking Hamas to investigate may have been a mistaken enterprise."

Goldstone concluded by addressing the central conundrum of post-9/11 ILOAC jurisprudence:

Simply put, the laws of armed conflict apply no less to non-state actors such as Hamas than they do to national armies. Ensuring that non-state actors respect these principles, and are investigated when they fail to do so, is one of the most significant challenges facing the law of armed conflict. Only if all parties to armed conflicts are held to these standards will we be able to protect civilians who, through no choice of their own, are caught up in war.

As important and as valuable as this admission is, it has too seldom been made a centerpiece of UN efforts as it should. Instead, the UN-and other governmental

\footnotetext{
8 Associated Press 2007.

9 Constable 2008, p. A12.

${ }^{10}$ Goldstone 2011.
} 
and nongovernmental organizations - too often appears to focus on the failings of the U.S, and other nation-states. The rationale seems clear, nonstate actors may be happy to assert allegations of war crimes and other misconduct against the U.S. and others, but are indifferent-truly indifferent- to allegations against themselves. Regrettably, as Goldstone's own efforts suggest, the UN has yet to resolve how to address incidents in a way that does not make them vulnerable to post hoc critiques that raise serious questions of fairness and equity.

From a U.S. perspective, some elements of the UN seem to revel in criticizing the American military. Perhaps the most insensitive was the scorn that UN Special Rapporteur, Phillip Alston leveled against American airmen operating remotely piloted vehicles (RPVs or commonly but inaccurately called "drones"). In his official report about extrajudicial killings he speculated about the aviators “developing a 'Playstation' mentality to killing."11 Exactly why this academic thought he was qualified to opine about the attitude of military professionals towards killing other human beings is unknown, but it is instructive that there is a plethora of evidence-apparently not considered by Alston-that demonstrates that the gravity of these duties causes many of the officers to suffer post-traumatic stress disorder (PTSD). ${ }^{12}$

The UN also seems fixated on airpower beyond just RPVs. A report issued by a UN agency in Afghanistan in 2011 misleadingly asserted that "Air strikes remained the leading cause of Afghan civilian deaths caused by Pro-Government Forces." ${ }^{13}$ The UN arrived at this statistic by consolidating all airstrike deaths into one category, while dividing ground-based deaths into three different "causes." Specifically, the UN allocated $32 \%$ of the civilian deaths at the hands of "pro-government" forces to "ground combat". Inexplicably excluded from that category were the "escalation of force" deaths $(12 \%)$ that refer to those killed at checkpoints and from fire from convoys. An additional 14\% of the deaths were attributed to another ground activity: night raids. Collectively, ground operations were responsible for some $58 \%$ of the deaths, considerably more than the airstrikes that the UN characterized as the "leading cause" of civilian deaths.

Even the UN's own judicial arm has come under fire. Professor John Norton Moore, the respected international lawyer from the University of Virginia, gave a scathing assessment of the United Nations' International Court of Justice's performance in a series of jus ad bellum cases, accusing it of "shocking failure[s] of legal craftsmanship." " if international law related to security matters - to include ILOAC - is to continue to evolve as a legal construct worthy of respect and deference.

\footnotetext{
11 Alston 2010, p. 25.

12 Reuters 2011.

13 United Nations Assistance Mission in Afghanistan 2011.

14 Moore forthcoming 2012.
} 


\subsection{The Role of Military Legal Advisors}

One of the most positive ILOAC trends of the post-9/11 era is the increased presence of lawyers, and especially military lawyers, in command centers and other venues where combat operations are being planned and carried out. Article 82 of Protocol I to the 1949 Geneva Conventions had long importuned state parties to ensure that legal advisers were "available," but exactly how effectively that was carried out prior to 9/11 was spotty, especially for nations other than the U.S. who either did not have large numbers of trained military lawyers, or who did not have any tradition of their involvement in matters other than military justice.

The rise of international law - and particularly "lawfare" — in the post-9/11 era did much to change that. Commanders, especially after the Abu Ghraib scandal, became keenly aware of the damage that illegalities could do to their operational objectives. As the New York Times reported, Air Force lawyers "vet" the targets to ensure the proposed bombing conforms "to a complex body of military law, including the Geneva Conventions, acts of Congress and court decisions." 15 Available to these military attorneys are sophisticated analytical tools to help them better evaluate targeting decisions. ${ }^{16}$ As a result, Human Rights Watch conceded that "[i]n their deliberate targeting, the Air Force has all but eliminated civilian casualties in Afghanistan." 17

General James Jones, the former commander of NATO, typified the new attitude of many senior commanders. While perhaps not especially evincing fondness for the legal profession, operational realities obliged him to admit that war in the twenty-first century had become "very legalistic and very complex" and now requires "a lawyer or a dozen." 18

\subsection{Accountability}

Internationalized justice related to armed conflict has had a mixed record since $9 / 11$. The apprehension of former Serb leader Slobodan Milošević in 2001 on a variety of war crimes led to real optimism about the feasibility of international tribunals. However, after 4 years of trial by the International Criminal Tribunal for the former Yugoslavia, the prosecution collapsed when Milošević died in 2006. The expensive and ultimately futile effort was hardly an endorsement of the global community's attempt to provide justice for war crimes' victims.

To be sure, there have been some successes, and the International Criminal Court (ICC) has made steady, albeit tortuously slow progress mainly by addressing

\footnotetext{
15 Shanker 2008.

16 Air Force 2009.

17 Shanker 2008.

18 Winik 2003.
} 
horrendous allegations of crimes arising out of African wars. Still, convictions have been few. Many believe that the absence of ratification of the Rome Statue by such nations as China, Russia, India and, especially, the United States is hampering prospects for real success.

That opposition, at least insofar as the U.S. is concerned, seems to be formally rooted in concern about politicized prosecutions of American officials. To oversimplify the concerns, U.S. negotiators want to ensure that actions taken in selfdefense, to include especially actions taken in anticipatory self-defense, do not become characterized as the war crime of "aggression." In that regard the Obama Administration seems to be taking steps toward reconciling U.S. concerns with the ICC by establishing a 7 year process with the real possibility of the U.S. becoming a party to the treaty. ${ }^{19}$

It is a mistake, however, to assume too much in this regard. Discussion surrounding the American Service-Members' Protection Act (a U.S. law which authorizes, among other things, the President to use "all necessary means" to free any U.S. person imprisoned or otherwise detained at the behest of the $\mathrm{ICC}^{20}$ ) suggests further issues. Specifically, the body politic of nation such as the U.S. that is dependent upon an all-volunteer force will not readily countenance the prospect of turning its soldiers over to a foreign entity for trial. It underestimates the importance to such volunteers of getting the benefit of the judicial system they are serving to protect.

No discussion of ILOAC accountability would be complete without some comment on the Haditha tragedy in Iraq in 2005. Twenty-four civilians, including children and elderly people, were killed by Marines, allegedly in retaliation for an improvised explosive device attack that killed a fellow Marine. While eight Marines were original accused of misconduct in the incident, only one was convicted-barely. In January of 2012 Staff Sergeant Frank D. Wuterich pled guilty to one minor charge of dereliction of duty.

The case and, indeed the handling of the entire incident, were rightly critiqued. The New York Times pointed out that although the military has convicted persons accused of unlawful killings in Iraq and Afghanistan, experts said that "the military and its justice system have repeatedly shown an unwillingness to second-guess the decisions made by fighters who said they believed they were in danger." 21

Importantly, however, civilian courts are not demonstrably different. In acquitting a former soldier of allegations of killing four Iraqi prisoners in 2004 in Fallouja, Iraq, one juror explained the not guilty verdict by saying "I think you don't know what goes on in combat until you are in combat." ${ }^{22}$ Another remarked "Who are we to decide what men in war are doing?"23

\footnotetext{
19 Rapp and Koh 2010.

20 Department of State 2003.

21 Savage 2012.

22 Associated Press 2008.

23 Perry 2008.
} 
Finally, one of the most daunting legal accountability issues faced by the international community in the post-9/11 era is not precisely an ILOAC matter. It is, however, a distinctly international security issue: pirates. Although the international community has enjoyed real success in dampening what had been a burgeoning threat, no real solution has been identified for the legal resolution of their case. ${ }^{24}$

\subsection{Terrorist Detention}

Few issues, save the use of coercive interrogation techniques, have been more controversial in the post-9/11 era than the detention of terrorists by the U.S. Many in the U.S. believe that the nation's political fortunes are at stake by the resolution of this issue. This belief may be misplaced as there is too often a rather na assumption in the U.S. that world opinion is more discerning than it really is.

For example, advocates of closing the detention facility at Guantanamo Bay seem to believe that once that is accomplished, peoples around the globe will suddenly embrace the American paradigm for addressing the long-term security threat posed by the relatively small but still potent number irreconcilable detainees committed to violence.

Underlying this issue are persisting misconceptions engendered by ill-advised U.S. policy pronouncements made shortly after 9/11. The announcement by then President Bush of his military commission order raised the expectation that all detainees would eventually face a trial. Many would understandably assume that such trials would take place in a timely manner and if the accused was acquitted, the detainee would be freed-as any other criminal suspect might.

Lost in this dialogue was the notion of law of war detention, that is, the wellestablished principle that belligerents who fall into the hands of their adversary may be held until the end of the conflict without trial and, in the case, of legitimate combatants, without criminal liability for their actions otherwise in compliance with ILOAC. Thus, the long-term detention of nonstate actors may well be necessary and, in any event, can be lawful.

Retreating from a well-established ILOAC principle in the hopes of gaining the global public's favor defies logic_-and may produce unintended and unwanted consequences. Actually, the more realistic view would hold that so long as the United States continues to detain terror suspects-regardless of location-critics will persist. This is especially so since it is likely that any other facility would be as well-equipped or as well-staffed as Guantanamo is today. In short, it is a wiser approach to keep to the proven ILOAC procedures and avoid attempts to "improve" upon it in order to gain the approval of those who may not have the

${ }^{24}$ Chivers 2012. 
responsibility for the security of those innocents who may be jeopardized by the release of those committed to violence.

\subsection{The Future}

Where will the future of ILOAC take us? For all the focus in the post-9/11 era on radical Islamic terror organizations, too little attention has been paid to the rise of a permutation on the threat posed by nonstate actors, that is, the emergence of what is ever more frequently being called "criminal insurgencies." These are entities that, unlike more traditional insurgencies', are not primarily driven by political or social aims, but simply by a need to neutralize or replace the coercive power of the state in order to be free to conduct their self-aggrandizing criminal activities.

One might rightly point out that criminal gangs with a similar raison d'être have long existed. The difference today is that the most dangerous of them are super-empowered by enormous profits produced principally by illicit drug trade. So vast have been the monies flowing into these criminal enterprises that they have been able to arm their gangs with an array of military weaponry including crewserved weapons, armored vehicles, aircraft, and even submarines. All of this is supported by a sophisticated communications systems, tunnel complexes and, perhaps most importantly, battalions of corrupted government officials.

The classic example of this phenomenon is Mexico. ${ }^{25}$ However, the Mexican government is loath to describe its security environment as any kind of insurgency even as it deploys its armed forces in a concerted effort to control its territory. While some might unhesitatingly characterize the situation as noninternational armed conflict and proceed accordingly, it may be that international law would be better served to evolve a model more suited to a situation where one of the belligerents has no agenda beyond an avowedly criminal one. In such circumstances there is no real possibility of a political settlement, yet at the same time norms which guarantee the protection of innocents might need further elaboration.

In any event, although many security experts believe that we are in an era of persistent, low-tech conflict against nonstate adversaries, it is also becoming increasing clear that the possibility of interstate warfare is not foregone. For the United States, disillusioned by costly wars in Iraq and Afghanistan against opponents who, for all their ruthlessness, do not—and cannot-pose an existential threat to the American homeland, there is increasing focus on the potential of selected nation-states to pose existential threats. Thus, the U.S. is engaged in a much-discussed "pivot" towards Asia, even as it recognizes conflicts in the Middle East and central Asia will be of continuing concern.

25 Grillo 2011. 
This Asia-focus may have interesting implications for ILOAC. In a 1999 interview, Col. Qia Liang and Col. Wang Xiangsui of the Chinese People's Liberation Army made this observation about ILOAC:

War has rules, but those rules are set by the West...if you use those rules, then weak countries have no chance...We are a weak country, so do we need to fight according to your rules? ${ }^{26}$

Moreover, in 2003 the Chinese Communist Party formalized the concept of "three warfares" one of which was "legal warfare." As recently explained by the U.S. Department of Defense (2011) these three warfares are designed to "undermine the spirit and ideological commitment of the adversary." Specifically, "legal warfare"

[U]ses international and domestic law to claim the legal high ground or assert Chinese interests. It can be employed to hamstring an adversary's operational freedom and shape the operational space. Legal warfare is also intended to build international support and manage possible political repercussions of China's military actions. China has attempted to employ legal warfare in the maritime domain and in international airspace in pursuit of a security buffer zone. ${ }^{27}$

Thus, although the term "lawfare" is not used, it seems clear that a form of it is intrinsic to Chinese planning. Accordingly, the international community must be ready to address not just the conundrums presented by a soon-to-be superpower's increasing military might, but also its obvious intent to leverage the law as a means and method of warfare. This is especially so under circumstances where the superpower itself may not feel particularly obliged to "fight according to..[the] rules."

\subsection{Conclusion}

This paper has only touched upon a few of the many ILOAC issues that have developed since 9/11. It was beyond the scope of this essay to address, for example, the merits of the profound and controversial issues raised, for example, by coercive interrogation techniques. Similarly, the complex issues of direct participation in hostilities by civilians were hardly mentioned. Likewise, although the issue of drones was mentioned, the far more challenging issue of fully autonomous weapons' systems was mentioned not at all, nor were the plethora of cyberwar matters eminently worthy of extended examination.

Clearly, there is no shortage of ILOAC subjects worthy of attention. Fortunately, there are an ever-expanding number of thoughtful lawyers around the globe who are engaging these concerns. It should be kept in mind that in this area of the

\footnotetext{
26 Pomfret 1999, p. A-1

27 DoD 2011.
} 
practice of law, competence demands far more than legal erudition. The practitioner must also be a student of the art of war, and all its many and varied aspects. It is an irreplaceable quality.

Finally, though the legacy of ILOAC in the post-9/11 era has been mottledsome bright spots marred by some very dark ones-one can still say that the evolution, as suggested in the beginning of this essay, has been far more beneficial than not. Perhaps the greatest legacy of this period is that law can-and doesevolve, so long as there are altruistic practitioners willing to devote themselves to its highest values and to the honorable profession which guides it.

\section{References}

Alston P (2010) Report of the special rapporteur on extrajudicial, summary or arbitrary execution: study on targeted killings, delivered to the Human Rights Council, U.N. Doc. A/ HRC/14/24/Add.6. http://www2.ohchr.org/english/bodies/hrcouncil/docs/14session/A.HRC. 14.24.Add6.pdf. Accessed 29 Jan 2012

Associated Press (2007) US Coalition Airstrikes Kill, Wound Civilians in Southern Afghanistan, official says. http://www.nydailynews.com/news/world/u-s-airstrikes-kill-wound-civilianssouthern-afghanistan-article-1.224856. Accessed 29 Jan 2012

Associated Press (2008) Federal jury acquits ex-Marine in Iraqis' deaths http://www.msnbc.msn. com/id/26443458/ns/world_news-mideast_n_africa/t/federal-jury-acquits-ex-marine-iraqisdeaths/

Chivers C (2012) Seized Pirates in High-Seas Legal Limbo, with No Formula for Trials http:// www.nytimes.com/2012/01/28/world/africa/seized-pirates-in-legal-limbo-with-no-formulafor-trials.html. Accessed 30 Jan 2012

Constable P (2008) NATO Hopes to Undercut Taliban with Surge of Projects. http:// www.washingtonpost.com/wp-dyn/content/article/2008/09/26/AR2008092603452_pf.html. Accessed 29 Jan 2012

Dunlap C (2001) Law and Military Operations: Preserving Humanitarian Values in 21st Century Conflicts. http://www.hks.harvard.edu/cchrp/Web\%20Working\%20Papers/Use\%20of\%20 Force/Dunlap2001.pdf. Accessed 29 Jan 2012

Dunlap C (2010) Does lawfare need an Apologia? 43 Case Western Reserve. J Int Law 43(1):121

Goldstein J (2011) Winning the War on War. Dutton

Goldstone R (2011) Reconsidering the Goldstone Report on Israel and war crimes. http://www. washingtonpost.com/opinions/reconsidering-the-goldstone-report-on-israel-and-war-crimes/ 2011/04/01/AFg111JC_story.html. Accessed 29 Jan 2012

Grillo I (2011) El Narco: inside Mexico's criminal insurgency. Bloomsbury Press, New York

Kudo T (2012) How the Marines video made the Afghan war even tougher. Washington Post http://www.washingtonpost.com/opinions/as-a-marine-and-afghan-war-vet-im-insulted-bythe-desecration-video/2012/01/12/gIQAswIrwP_story.html. Accessed 29 Jan 2012

Moore $\mathbf{J}$ (forthcoming) Jus ad Bellum: Before the International Court of Justice http://www.vjil. org/information/current/forthcoming. Accessed May 2012

Perry T (2008) IRAQ: For Jose Nazario, the trial and the war are over http://latimesblogs. latimes.com/babylonbeyond/2008/08/iraq-for-jose-n.html. Accessed 30 Jan 2012

Pomfret J (1999) China ponders new rules of 'Unrestricted War'. Washington Post, at A-1

Rapp S, Koh H (2010) Briefing on the International Criminal Court Conference in Kampala, Uganda. http://www.state.gov/j/gcj/us_releases/remarks/142585.htm. Accessed 30 Jan 2012

Reisman W, Antoniou C (1994) The laws of war. Random House, New York 
Reuters (2011) Overstretched drone pilots face stress risk. http://www.reuters.com/article/2011/ 12/18/us-usa-drones-stress-idUSTRE7BH0VH20111218. Accessed 30 Jan 2012

Savage C (2012) An Iraqi Massacre, a Light Sentence and a Question of Military Justice. http:// www.nytimes.com/2012/01/28/us/an-iraqi-massacre-a-light-sentence-and-a-question-ofmilitary-justice.html?ref=world. Accessed 30 Jan 2012

Shanker T (2008) Civilian Risks Curb Strikes in Afghan War. http://www.nytimes.com/2008/07/ 23/world/asia/23military.html. Accessed 29 Jan 2012

United Nations Assistance Mission in Afghanistan (2011) Afghanistan Midyear Report 2011: Protection of Civilians in Armed Conflict. http://unama.unmissions.org/Portals/UNAMA/ Documents/2011\%20Midyear\%20POC.pdf. Accessed 30 Jan 2012

U.S. Department of the Air Force (2009) Targeting and Weaponeering. http://www.afjag.af.mil/ shared/media/document/AFD-100510-059.pdf. Accessed 30 Jan 2012

U.S. Department of Defense (2011) Military and Security Developments Involving the People's Republic of China. http://www.defense.gov/pubs/pdfs/2011_CMPR_Final.pdf. Accessed 29 Jan 2012

U.S. Department of Defense (2009) Press Conference with Secretary Gates and Adm. Mullen on Leadership Changes in Afghanistan from the Pentagon. http://www.defense.gov/transcripts/ transcript.aspx?transcriptid=4424. Accessed 30 Jan 2012

U.S. Department of State (2003) American Service-Members' Protection Act. http://www.state. gov/t/pm/rls/othr/misc/23425.htm. Accessed 29 Jan 2012

Winik W (2003) A Marine's Toughest Mission (Gen. James L. Jones), http://www.parade.com/ articles/editions/2003/edition_01-19-2003/General_Jones. Accessed 30 Jan 2012 